\title{
Uvajanje načel vitkega proizvajanja v izbranem podjetju
}

\author{
Sabina Zidar* \\ Univerza na Primorskem, Fakulteta za management, Cankarjeva 5, 6000 Koper, Slovenija \\ sabina.zidar@gmail.com
}

Mirko Markič

Univerza na Primorskem, Fakulteta za management, Cankarjeva 5, 6000 Koper, Slovenija mirko.markic@fm-kp.si

\begin{abstract}
Povzetek:
Raziskovalno vprašanje (RV): Kakšna je stopnja usposobljenosti o vitkem proizvajanju? Namen: Opraviti empirično raziskavo o uvajanju vitkega proizvajanja in usposobljenosti o vitkosti in ugotoviti, kakšno je mnenje anketiranih o vpeljavi vitkega proizvajanja.

Metoda: Na vzorcu 342 zaposlenih sodelavcev v izbranem podjetju smo opravili kvantitativno raziskavo o usposobljenosti in uvajanju načel vitkega proizvajanja.

Rezultati: Ključna ugotovitev je, da več ur usposabljanja pomeni boljše poznavanje terminologije vitkega proizvajanja in namena vitkega podjetja.

Organizacija: Zasnovali smo predloge za izboljšanje stanja na področju usposobljenosti in uvajanju načel vitkega proizvajanja.

Družba: Ugotovitve iz raziskave bodo imele teoretične in praktične implikacije za vse tiste, ki se ukvarjajo z vpeljevanjem načel vitkega proizvajanja.

Originalnost: Izvirna raziskava s področja usposobljenosti zaposlenih o vitkem proizvajanju v Republiki Sloveniji.

Omejitve/nadaljnje raziskovanje: Raziskavo smo opravili v enem proizvajalnem podjetju, zato izidov ne bo mogoče posploševati na druga podjetja in na druge dejavnosti.
\end{abstract}

Ključne besede: menedžment, proizvajanje, usposabljanje, vitko proizvajanje.

\section{Uvod}

Začetek vitkega proizvajanja umestimo na prehod 20. stoletja, ko je Sakichi Toyoda, ustanovitelj podjetja Toyota, prešel iz tekstilne dejavnosti na proizvajanje avtomobilov. Taiichi Ohno je z uveljavitvijo načel Toyotinega sistema proizvajanja (Toyota Production System - v nadaljevanju: TPS) postavil temelje za poslovno-organizacijski sistem vitkega proizvajanja, kot ga poznamo še danes (Kešetović 2012, str. 227). TPS je sistemski proces za izboljšanje poslovanja v podjetju, ki mu omogoča znižanje stroškov (Stewart 2012, str. 11).

Ko govorimo o vitkem proizvajanju, si predstavljamo podjetje, v katerem si nenehno prizadevajo za izboljšanje svojih proizvajalnih, tržnih in finančnih dejavnosti. To je podjetje, v 
katerem naj bi se nenehno razvijali in odpravljali izgube, potrate in napake $\mathrm{v}$ vseh delovnih procesih, pri katerih nastaja proizvod (izdelek ali storitev). Namen vitkega proizvajanja je nenehno izboljšanje vseh bistvenih dejavnosti v podjetju. Vitko proizvajanje ni sklop določenih dejavnosti, ki jih uvedejo v podjetju in bodo delovali bolje. Je sprememba miselnosti, filozofije in delovanja, ki naj bo trajna. Uvedba vitkega proizvajanja je eden izmed najcenejših načinov povečanja prilagodljivosti, kakovosti in zadovoljitve kupcev (Agencija Poti 2013).

Namen naše raziskave je bil preučiti literaturo s področja vitkega proizvajanja, predvsem pa ugotoviti, kako poteka uvajanje načel vitkega proizvajanja v izbranem podjetju in kako so zaposleni usposobljeni o načelih vitkega proizvajanja. $\mathrm{V}$ ta namen smo v izbranem podjetju opravili kvantitativno raziskavo. Na podlagi prepoznanega raziskovalnega problema in zasnovanega vprašalnika o vitkem podjetju smo formirali hipoteze, ki smo jih v empiričnem delu raziskave preverili in obrazložili.

\section{Teoretična izhodišča}

Vitko proizvajanje pomeni usmeritev v odstranjevanje vseh vrst izgub na vsakem področju proizvajanja, upoštevajoč usmeritev na zahteve kupca, proizvod, dobaviteljsko verigo in menedžment podjetja ali druge organizacije. Namen vitkega proizvajanja je doseči čim enostavnejše obvladovanje procesov proizvajanja $z$ manj človeškega napora, s čim manj izgubami (npr. za čakanje, zaloge, transport, kakovost, napačno vključeni (vodeni) ljudje ipd.) (Gošnik 2018, str. 24). Ljubič (2000, str. 417) piše: »Sodobna proizvodnja zahteva predvsem čim krajše pretočne čase in proizvodni interval ob hkratnih čim manjših zalogah, čim večji prilagodljivosti zahtevam kupcev (personalizacija) in kakovostne izdelke brez napak. " Page (2002, str. 3) navaja: »Izguba je vsaka aktivnosti, ki porablja sredstva in ne prinaša dodane vrednosti za kupca. Ljubič (2000, str. 418- 419) navaja: 7-W-jev, dejavnike, ki povzročajo stroške in ne prinašajo nove vrednosti: »waste of overproduction« - odvečno, preveliko proizvajanje (napačno planiranje, zaradi varnostnih zalog je izdelanih več izdelkov, kot je potrebno; (Unterlechner in drugi 2009, str. 149) navajajo: »Tudi delati hitreje samo zato, da dobimo čim večji izkoristek dela zaposlenih, je zgolj druga oblika čezmernega proizvajanja in dejansko vodi k splošnemu čezmernemu zaposlovanju. Izdelke je potrebno izdelovati v taktu, kot ga želi odjemalec.«; navajajo naslednje dejavnike, ki povzročajo stroške: »odvečne zaloge (po asortimentu), prevelike nepotrebne zaloge materialov in nedokončanega proizvajanja; odvečno čakanje, neobjektivni medoperacijski zastoji; odvečni gibi, neracionalno oblikovana delovna mesta in načini dela; odvečni transport; odvečni izmet in izdelki z napakami in odvečne obdelave, neracionalni (tehnološki) postopki proizvajanja«. Liker (2004, str. 29) dodaja še osmi dejavnik, ki povzroča stroške: neizkoriščena ustvarjalnost zaposlenih (unused employee creativity). Gre za izgubljanje časa, idej, veščin, izboljšav in priložnost za učenje, ker zaposlenih ne vključujemo in jih ne poslušamo. Glavni vzrok, da v podjetju ne dosegajo načel vitkosti, oziroma največja potrata so presežno proizvajanje in posledične skladiščne zaloge. Kadar menedžerji dopuščajo zaloge proizvodov, te učinkujejo negativno in vodijo do suboptimalnega vedenja in obnašanja udeležencev $\mathrm{v}$ delovnih procesih, saj s tem prekrivajo 
večino težav in anomalij nepravilno delujočih delovnih procesov (Unterlechner in drugi 2009, str. 187). Pučko (1993, str. 432) ugotavlja: »Zaloge se nam v podjetju pojavljajo predvsem zato, da si omogočimo sorazmerno neodvisnost posameznih faz poslovnega procesa in dogajanja $v$ njih. To omogoča opravljanje vsake faze na najbolj učinkovit način. S tem je mogoče stroške vsake faze znižati. Po drugi stani pa to zahteva obstoj zalog, ki pomenijo vezavo finančnih sredstev in nastajanje stroškov, vezanih na njihov obstoj (stroški financiranja, zavarovanja, skladiščnega prostora ...). Od tod izhaja, da je nujno hkrati uravnotežiti stroške posameznih faz poslovnega procesa in stroške zalog. Šele ko je vsota vseh teh stroškov minimalna, so zaloge optimalne.« Maurya (2014, str. 33) pravi: "Čudežnih rešitev ni, saj nobena metoda ne zagotavlja uspeha. $Z$ dobro metodo pa lahko ustvarimo povratno zanko, ki omogoča nenehne izboljšave in učenje."

Tematika vitkega proizvajanja zanima tudi slovenske raziskovalce in praktike. $Z$ namenom, da bi prišli do potrebnih podatkov za našo raziskavo smo opravili pregled ugotovitev iz diplomskih ter magistrskih nalog s področja vitkega proizvajanja, ki so bile do sedaj izvedene v RS in jih na kratko povzemamo v nadaljevanju. Radoševič (2008) je prikazal, kako bi lahko z vpeljavo prvin vitkega proizvajanja povečali produktivnost pri proizvajanju notranjih vrat. Z raziskavo je ugotovil, da je ob upoštevanju načel vitkosti ter investiranju v nekaj ključnih posodobitev strojne opreme možno povečati produktivnost za $25 \%$. Molnar (2009) je proučevala uvajanje vitkega proizvajanja na področju trdnih farmacevtskih oblik. Predstavljen je projekt uvajanja in primer s katerim so dosegli številne izboljšave, ki se kažejo v večji produktivnosti in nižjih proizvodnih stroških. Zigmund (2009) je s pomočjo proučevanja teorije in analize planiranja ter vodenja proizvajanja $v$ podjetju predlagala izboljšave pri sestavi vratnih zapor in zmanjšanje nepotrebnih zalog. Idejna zasnova rešitve temelji na osnovnem modelu kanbana. Oražem (2010) je prikazal potek procesa prenove proizvajanja avtomobilskih delov v izbranem podjetju z uporabo metodologije Šest sigma vitkega proizvajanja. Analiziral je težave pri vpeljavi novega sistema, ki so se pokazale predvsem v razumevanju in spremembi kulture obnašanja zaposlenih in podal tudi izvirne rešitve na področju vodenja in nagrajevanja. Ferjančič (2011) se je osredotočil na uvajanje vitkega proizvajanj v izbranem podjetju. Vprašalnik je izdelal na osnovi Fordovega pristopa ocenjevanja. Analiza obstoječega stanja je pokazala, da na različnih področjih dosegajo različne nivoje vitkosti, na vseh področjih pa imajo še veliko priložnosti za izboljšave. Sečki (2011) je preverjal pomen vitkosti v proizvodnih podjetjih, hkrati pa nakazuje, kje ima Slovenija še rezerve na področju učinkovitosti s pomočjo vitkosti. Spoznal je, da so bile za marsikoga od predstavnikov podjetij to metode za katere sploh še niso slišali ali pa mogoče le bežno. Vergot (2011) na teoretičnih in praktičnih primerih opisuje uvajanje načel vitkega proizvajanja in pilotni projekt, ki se je izvajal na oddelku kolenaste gredi. S pilotnim projektom jim je uspelo uvesti nekatere organizacijske spremembe predvsem vpeljava timskega koordinatorja. Povečalo se je zadovoljstvo zaposlenih, izboljšala se je komunikacija in $5 \mathrm{~S}$ metoda je bila dobro sprejeta. Črešnar (2012) se je podrobneje osredotočila na vitko proizvajanje, s poudarkom na sistemu kanban, ki je eden izmed gradnikov vitkega proizvajanja. V delu je prikazan primer vpeljave kanbana in njegovo delovanje v praksi. Piškor (2012) je z uporabo orodij za doseganje vitkega proizvajanja v podjetju Oprema-Uredaji d.o. prikazal šibka 
mesta obstoječega proizvodnega procesa $\mathrm{v}$ podjetju, ter podane rešitve prenove oziroma na novo načrtovane operacije proizvodnega procesa. Šverko (2012) je obravnaval možnost uvajanja načel vitkosti $\mathrm{v}$ izdelovanju avtomobilskih žarometov. Obravnaval je način optimiranja izdelovalnega procesa montaže žarometov. V sklepu je podal kritično oceno doseženega stanja, možnosti nadaljnjih izvajanj in nevarnosti, da uvedene rešitve ne bodo obstale dolgoročno. Strašek (2013) je predstavil začetek procesa implementacije koncepta vitkega proizvajanja v proizvodnem podjetju in njen vpliv na proizvodni proces. Predstavil je metode, ki sestavljajo koncept vitkega proizvajanja s poudarkom na metodi SMED. Leskovšek (2014) je raziskala in prikazala, kakšna je specifika planiranja v vitkih proizvodnih sistemih in kako se razlikuje od planiranja $\mathrm{v}$ masovni proizvodnji. S pomočjo raziskave je spoznala kako vpeljava vitkih načel proizvajanja v procese vpliva na samo planiranje.

Po opredelitvi teoretičnih izhodišč in sistematičnem pregledu dosedanjih raziskav s področja vitkega proizvajanja smo ugotovili, da je tematika zanimiva tako za teoretike, raziskovalce in praktike $\mathrm{v}$ podjetjih. $\mathrm{Z}$ dosedanjimi raziskavami so se avtorji ukvarjali predvsem z operativnim področjem v posameznem delovnem procesu in manj z izhodišči zanj. Ob pregledu dosedanjih raziskav namreč nismo zasledili, da bi kdo že anketiral zaposlene sodelavce in jih spraševal kako so izobraženi oz. usposobljeni o vitkem proizvajanju. $\mathrm{Na}$ ta način smo evidentirali raziskovalno vrzel, ki jo bomo poizkusili z našo raziskavo vsaj delno zapolniti. Na ta način bomo prišli do novih znanj, ki bodo imela teoretične in predvsem praktične koristi za izbrano organizacijo in širšo družbeno skupnost.

$\mathrm{Na}$ podlagi pregleda strokovne literature, identificiranega raziskovalnega problema in zasnovanega vprašalnika smo formirali naslednje hipoteze:

H1: Poznavanje terminologije in namena vitkega proizvajanja sta na nizki ravni.

H2: Poznavanje namena in terminologije vitkega proizvajanja je boljše z večjim številom ur usposabljanja.

H3: Z višjo formalno izobrazbo je poznavanje namena in terminologije vitkega proizvajanja boljše.

\section{Metoda}

$\mathrm{V}$ teoretičnem delu raziskave smo uporabili metodo deskripcije in metodo kompilacije, kjer je šlo za povzemanje in interpretacijo misli drugih avtorjev (Zelenika 2000, str. 338). V teoretičnem delu raziskave podajamo pregled domače in tuje strokovne literature s poudarkom na konkretnih raziskavah o tematiki vitkega proizvajanja v RS. Pregledali smo do sedaj že objavljene diplomske in magistrske naloge s področja vitkega proizvajanja. Ustrezno literaturo smo iskali s pomočjo baze COBISS, v revijah (Strojniški vestnik; IRT 3000; Organizacija; Management; RUO - Revija za univerzalno odličnost ipd.) in po naslednjih ključnih besedah: 
anketa, menedžment, proizvajanje, usposabljanje in vitko proizvajanje. Teoretični del je obsegal študijo sekundarnih virov.

Kvantitativna raziskava o usposobljenosti in uvajanju načel vitkega proizvajanja v izbranem podjetju je predstavljala empirični del raziskovanja. Populacija je bila 800 oseb, ki so bile zaposlene v izbranem podjetju na dan anketiranja. Namenski vzorec je obsegal 342 zaposlenih v izbranem podjetju. Vprašalnik je bil sestavljen iz trinajstih vprašanj. Pred anketiranjem smo izvedli testiranje vprašalnika $\mathrm{v}$ izbranem podjetju na vzorcu petih zaposlenih. Vprašalnik smo zaposlenim $\mathrm{v}$ izbranem podjetju posredovali na njihove službene elektronske naslove. $\mathrm{V}$ empiričnem delu smo izvedli raziskavo z anketiranjem. Pridobljene podatke smo analizirali z naslednjimi metodami: t-testom, Pearsonovim korelacijskim koeficientom in ANOVO.

Hipotezo H1 smo preverjali s t-testom za en vzorec. Najprej smo ustvarili novo spremenljivko Poznavanje terminologije in namena vitkega proizvajanja tako, da smo združili trditve v vprašalniku, ki so pod 1. sklopom (poznavanje terminologije vitkega proizvajanja in namen vitkega podjetja). Za mejo, od katere naprej smo menili, da je poznavanje na visoki ravni, smo si izbrali povprečje 3. Nato smo s t-testom preverili, ali se dejansko povprečje nove spremenljivke razlikuje od naše meje 3 . Če je bilo statistično pomembno manjše od 3 , smo hipotezo potrdili, saj bo Poznavanje terminologije vitkega proizvajanja in namen vitkega podjetja na nizki ravni.

Hipotezo H2 smo preverjali s Pearsonovim korelacijskim koeficientom. Najprej smo ustvarili novo spremenljivko Poznavanje terminologije in namena vitkega proizvajanja tako, da smo združili trditve $\mathrm{v}$ vprašalniku, ki so pod 1. sklopom (poznavanje terminologije vitkega proizvajanja in namen vitkega podjetja). Nato smo merili korelacijo med to novo spremenljivko in številom ur usposabljanja. Če je bila korelacija statistično pomembna in pozitivna, smo hipotezo potrdili, saj je to pomenilo, da več ur kot so se usposabljali, bolje poznajo terminologijo.

Hipotezo H3 smo preverjali z ANOVO oz. analizo variance. Najprej smo ustvarili novo spremenljivko Poznavanje terminologije in namena vitkega proizvajanja in jo preverjali tako, da smo združili trditve $\mathrm{v}$ vprašalniku, ki so bile pod 1. sklopom (poznavanje terminologije vitkega proizvajanja in namen vitkega podjetja). $Z$ analizo variance skupin smo preverili, ali se skupine ( $v$ našem primeru glede stopnje formalne izobrazbe) v povprečju med seboj statistično pomembno razlikujejo. Če so bile razlike glede na stopnjo izobrazbe statistično značilne, smo hipotezo potrdili.

Za analiziranje tako pridobljenih podatkov in informacij smo uporabili program Statistical Package for the Social Sciences (v nadaljevanju: SPSS) in program Microsoft Excel. 


\section{Rezultati}

\subsection{Opis vzorca}

Ustrezno izpolnjenih je bilo 282 vprašalnikov, kar je predstavljalo $82 \%$ odzivnost.

Kot je razvidno iz Preglednice 1 in strukture anketiranih po izobrazbi, je imela večina anketiranih srednjo izobrazbo, sledi višja in visoka. Najmanj anketiranih je imelo končan magisterij ali doktorat. Struktura anketiranih po starosti kaže, da je bilo največ anketiranih starih od 41 do 60 let, sledijo anketiranci v starosti 21 do 40 let. Kot je razvidno iz preglednice 1, smo največ odgovorov dobili iz podružnice Magma.

Preglednica 1. Struktura anketiranih po izobrazbi, starosti, po organizacijskih enotah

\begin{tabular}{|c|c|c|}
\hline & Frekvenca & Delež (v \%) \\
\hline \multicolumn{3}{|l|}{ Izobrazba } \\
\hline Osnovna & 1 & 1,0 \\
\hline Poklicna & 6 & 6,0 \\
\hline Srednja & 38 & 38,0 \\
\hline Višja & 27 & 27,0 \\
\hline Visoka & 22 & 22,0 \\
\hline Magisterij & 5 & 5,0 \\
\hline Doktorat & 1 & 1,0 \\
\hline Skupaj & 100 & 100,0 \\
\hline \multicolumn{3}{|l|}{ Starost v letih } \\
\hline do 20 let & 1 & 1,0 \\
\hline $21-40$ let & 41 & 41,0 \\
\hline $41-60$ let & 56 & 56,0 \\
\hline 61 let ali več & 2 & 2,0 \\
\hline Skupaj & 100 & 100,0 \\
\hline \multicolumn{3}{|l|}{ Podružnica/oddelek } \\
\hline Divizija A & 12 & 12,4 \\
\hline Divizija B1 & 7 & 7,2 \\
\hline Divizija B0 & 14 & 14,4 \\
\hline Logistika & 13 & 13,4 \\
\hline Podružnica Dekani & 1 & 1,0 \\
\hline Podružnica Kočevje & 8 & 8,2 \\
\hline Podružnica Magma & 17 & 17,5 \\
\hline Vzdrževanje & 7 & 7,2 \\
\hline Vlek & 3 & 3,1 \\
\hline Razvoj in tehnologija & 14 & 14,4 \\
\hline Kakovost & 1 & 1,0 \\
\hline Skupaj & 97 & 100,0 \\
\hline
\end{tabular}




\subsection{Poznavanje terminologije vitkega proizvajanja}

Ugotovili smo, da so se anketirani v povprečju najbolj strinjali s trditvijo, da vedo, kaj pomeni izraz vitko proizvajanje, in vedo, katera so njena orodja. Nekoliko slabše povprečje smo dobili pri trditvah, da o vitkem proizvajanju vedo toliko, da lahko svoje znanje delijo naprej, in da so dovolj usposobljeni. Najbolj se anketirani strinjajo s trditvijo, da je pomembno sodelovati in biti pripravljen na spremembe, saj je to bistveno za uspeh. Sledi odgovor, da so svoje vrednote, znanje in veščine o vitkem proizvajanju pripravljeni uporabljati pri svojem delu in znanje deliti naprej ter da menijo, da vpeljava načel vitkega proizvajanja izboljša učinkovitost poslovanja in konkurenčnost podjetja. Vpeljava vitkega proizvajanja je pomembna, saj že pomaga pri znižanju in obvladovanju zalog v podjetju. Anketirani so se najmanj strinjali s trditvijo, da je vitko proizvajanje nesmiselno ter da je sedaj dobro tako, kot je, saj delajo dovolj dobro. V povprečju je največ anketiranih poznalo izraze kanban, $5 \mathrm{~S}$, JIM in TPM. Slabše so poznali izraze One Piece Flow, PDCA, SMED in Poka-Yoke, zelo slabo pa so poznali izraze Heijunka, Jidoka, Value Stream Mapping in Kaizen. V povprečju so anketirani največ uporabljali orodja: 5 S, TPM, kanban, SMED, najmanj pa Heijunka, Jidoka, Value Stream Mapping in One Piece Flow. Menili so, da so najbolj učinkovita orodja za doseganje vitkega proizvajanja kanban, SMED, 5 S, TPM, PDCA in JIT, najmanj pa so se jim zdela učinkovita Heijunka, Jidoka, Value Stream Mapping ter One Piece Flow. V povprečju je večina anketiranih menila, da so za nižanje zalog najbolj pomembna stabilna naročila in pravočasne informacije o potrebah in zahtevah kupcev ter redne in točne dobave vhodnih materialov; sledijo kakovost proizvoda ali procesa ter natančno planiranje (terminiranje) in vodenje proizvajanja. Anketirani so ocenili stopnjo vitkosti v podjetju in v veliki večini menili, da je to nekje na srednji ravni, vendar bo na tem področju potrebnega še veliko dela. Približno polovica anketiranih se je že udeležila usposabljanja na temo vitkega proizvajanja. Tisti, ki so se usposabljanja udeležili, so se usposabljali v povprečju 14,8 ur. Anketirani, ki so podali predloge glede vpeljave vitkega proizvajanja v podjetje, predlagajo dejavnosti v okviru strateške teme vitkega proizvajanja, več usposabljanj na vseh ravneh organiziranosti, boljše ozaveščanje sodelavcev, prenos znanja, pravočasno planiranje, točnejše napovedi od kupcev, hitro menjavo orodij ipd.

\subsection{Preverjanje hipotez}

V nadaljevanju bomo predstavili interpretacijo preverjanja formiranih hipotez.

H1: Poznavanje terminologije in namena vitkega proizvajanja sta na nizki ravni.

Zanimalo nas je, ali je poznavanje terminologije in namena vitkega proizvajanja na nizki ravni. Hipotezo smo preverjali s t-teston za en vzorec. Najprej smo ustvarili novo spremenljivko Poznavanje terminologije in namena vitkega proizvajanja tako, da smo združili trditve v vprašalniku, ki so pod 1. sklopom (Poznavanje terminologije vitkega proizvajanja in namen vitkega podjetja). Za mejo, od katere naprej menimo, da je poznavanje na visoki ravni, smo si izbrali povprečje 3. Nato smo s t-testom preverili, ali se dejansko povprečje nove spremenljivke razlikuje od naše meje 3. Če bo statistično pomembno manjše od 3, bomo hipotezo potrdili, saj bo Poznavanje terminologije vitkega proizvajanja in namen vitkega podjetja na nizki ravni. 
Preglednica 2. Opisna statistika

\begin{tabular}{lcccc}
\hline & $\mathrm{N}$ & Povprečje & $\begin{array}{c}\text { Std. } \\
\text { odklon }\end{array}$ & $\begin{array}{c}\text { Std. napaka } \\
\text { povprečja }\end{array}$ \\
\hline $\begin{array}{l}\text { Poznavanje terminologije vitkega } \\
\text { proizvajanja in namen vitkega podjetja }\end{array}$ & 137 & 3,48 & 0,74 & 0,06 \\
\hline
\end{tabular}

Statistična pomembnost p-vrednost znaša $0,00(\mathrm{p}<3)$, kar kaže, da je povprečje višje in se pomembno razlikuje od testne vrednosti.

Preglednica 3. T-test za en vzorec

\begin{tabular}{|c|c|c|c|c|c|c|}
\hline & \multicolumn{6}{|c|}{ Testna vrednost $=3.00$} \\
\hline & $\mathrm{t}$ & df & $\begin{array}{l}\text { P-vrednost } \\
\text { (2-stranska) }\end{array}$ & $\begin{array}{l}\text { Razlika v } \\
\text { povprečju }\end{array}$ & $\begin{array}{l}95 \% \text { interval } \\
\text { Nizki }\end{array}$ & $\begin{array}{l}\text { zaupanja } \\
\text { Visoki }\end{array}$ \\
\hline $\begin{array}{l}\text { Poznavanje terminologije } \\
\text { vitkega proizvajanja in namen } \\
\text { vitkega podjetja }\end{array}$ & 7,629 & 136 & 0,00 & 0,48 & 0,36 & 0,61 \\
\hline
\end{tabular}

Glede na povprečno vrednost hipotezo, da je poznavanje terminologije in namena vitkega proizvajanja na nizki ravni, zavrnemo.

H2: Poznavanje namena in terminologije vitkega proizvajanja je boljše z večjim številom ur usposabljanja.

Zanimalo nas je, ali je poznavanje namena in terminologije vitkega proizvajanja boljše z večjim številom ur usposabljanja. Za preverbo hipoteze smo uporabili Pearsonov korelacijski koeficient, s katerim smo preučevali povezanost med dvema spremenljivkama oziroma vprašanjema.

\section{Preglednica 4. Opisna statistika}

\begin{tabular}{lrrr}
\hline & Povprečje & St. odklon & \multicolumn{1}{c}{$\mathrm{N}$} \\
\hline $\begin{array}{l}\text { Poznavanje terminologije vitkega proizvajanja in namen vitkega } \\
\text { podjetja }\end{array}$ & 3,48 & 0,74 & 137 \\
Koliko ur ste se usposabljali & 14,76 & 18,54 & 55 \\
\hline
\end{tabular}

Pearsonov korelacijski koeficient znaša 0,296 in je statistično značilen (preglednica 5). Vrednost $\mathrm{P}$ je pod 0,05. Lahko govorimo o pozitivni povezanosti spremenljivk. Moč povezanosti je nizka/šibka. Hipotezo lahko potrdimo. Več ur usposabljanja pomeni boljše poznavanje terminologije vitkega proizvajanja in namena vitkega podjetja. 
Preglednica 5. Korelacije

\begin{tabular}{|c|c|c|c|}
\hline & & $\begin{array}{l}\text { Poznavanje terminologije vitkega } \\
\text { proizvajanja in namen vitkega } \\
\text { podjetja }\end{array}$ & $\begin{array}{l}\text { Koliko ur } \\
\text { ste se } \\
\text { usposabljali }\end{array}$ \\
\hline \multirow{3}{*}{$\begin{array}{l}\text { Poznavanje } \\
\text { terminologije vitkega } \\
\text { proizvajanja in namen } \\
\text { vitkega podjetja }\end{array}$} & $\begin{array}{l}\text { Pearsonov koeficient } \\
\text { korelacije }\end{array}$ & 1 & $0,296^{*}$ \\
\hline & $\begin{array}{l}\text { Asimp. p-vrednost } \\
\text { (2-stranska) }\end{array}$ & & 0,028 \\
\hline & $\mathrm{N}$ & 137 & 55 \\
\hline \multirow[t]{3}{*}{$\begin{array}{l}\text { Koliko ur ste se } \\
\text { usposabljali }\end{array}$} & $\begin{array}{l}\text { Pearsonov koeficient } \\
\text { korelacije }\end{array}$ & $0,296^{*}$ & 1 \\
\hline & $\begin{array}{l}\text { Asimp. p-vrednost } \\
\text { (2-stranska) }\end{array}$ & 0,028 & \\
\hline & $\mathrm{N}$ & 55 & 55 \\
\hline
\end{tabular}

H3: Z višjo formalno izobrazbo je poznavanje namena in terminologije vitkega proizvajanja boljše.

Zanimalo nas je, ali se poznavanje namena in terminologije vitkega proizvajanja viša z višjo formalno izobrazbo. Določene izobrazbene kategorije smo po vsebinski smiselnosti združili.

Preglednica 6. Stopnja izobrazbe

\begin{tabular}{lrr}
\hline & Frekvenca & \\
\hline OŠ in poklicna & 7 & Delež (v \%) \\
Srednja & 38 & 7,1 \\
Višja in visoka & 49 & 38,4 \\
Magisterij in doktorat & 5 & 49,5 \\
\hline Skupaj & 99 & 5,1 \\
\hline
\end{tabular}

Izračunali smo frekvenco in delež glede na stopnjo izobrazbe. S statistično analizo smo želeli ugotoviti, ali se znotraj izobrazbene strukture anketiranih pojavljajo statistično značilne razlike v povprečjih glede poznavanja terminologije vitkega proizvajanja in namena vitkega podjetja. Za analizo smo porabili ANOVO oz. analizo variance. $Z$ analizira variance skupin smo preverili, ali se skupine (v našem primeru glede izobrazbe) v povprečju med seboj statistično pomembno razlikujejo. 


\begin{tabular}{|c|c|c|c|c|c|c|c|c|}
\hline & \multirow[t]{2}{*}{$\mathrm{N}$} & \multirow{2}{*}{ Povpr. } & \multirow{2}{*}{$\begin{array}{l}\text { Std. } \\
\text { odklon }\end{array}$} & \multirow{2}{*}{$\begin{array}{c}\text { Std. } \\
\text { napaka }\end{array}$} & \multicolumn{2}{|c|}{$\begin{array}{c}95 \% \text { interval } \\
\text { zaupanja povprečja }\end{array}$} & \multirow{2}{*}{ Min. } & \multirow{2}{*}{ Maks. } \\
\hline & & & & & Nizki & Visoki & & \\
\hline OŠ + poklicna & 7 & 3,76 & 0,61 & 0,23 & 3,20 & 4,32 & 3,08 & 4,92 \\
\hline Srednja & 38 & 3,52 & 0,73 & 0,12 & 3,29 & 3,76 & 1,00 & 4,38 \\
\hline Višja + Visoka & 49 & 3,64 & 0,60 & 0,09 & 3,47 & 3,81 & 1,23 & 4,46 \\
\hline Magisterij + doktorat & 5 & 3,77 & 0,19 & 0,08 & 3,54 & 4,00 & 3,62 & 4,08 \\
\hline Skupaj & 99 & 3,61 & 0,64 & 0,06 & 3,48 & 3,74 & 1,00 & 4,92 \\
\hline
\end{tabular}

Preglednica 8. Test homogenosti varianc

\begin{tabular}{cccc}
\hline Leveneova statistika & df1 & df2 & Asimp. p-vrednost \\
\hline 1,52 & 3 & 95 & 0,21 \\
\hline
\end{tabular}

Ali so variance skupin homogene, preverimo z Levenovim testom homogenosti varianc. Če so variance homogene, pomeni, da med variancami skupin ni statistično pomembnih razlik. Statistična pomembnost testa homogenosti varianc (Levenov test) znaša 0,21, razlike med variancami niso statistično pomembne $(p>0,05)$ in lahko sprejmemo predpostavko o homogenosti varianc.

Preglednica 9. Enosmerna analiza variance - ANOVA

\begin{tabular}{ccc}
\hline Povprečje kvadratov & F & Asimp. p-vrednost \\
\hline 0,202 & 0,490 & 0,690 \\
\hline
\end{tabular}

Statistična pomembnost enosmerne analize variance znaša 0,690, kar kaže, da so razlike med variancami glede na stopnjo izobrazbe statistično nepomembne in ne moremo trditi, da je poznavanje namena in terminologije vitkega proizvajanja boljše z višjo formalno izobrazbo. Hipotezo zavrnemo.

\section{Razprava}

Izhajamo iz rezultatov, ki smo jih dobili pri hipotezi H1, kjer smo glede na izračunano povprečno vrednost hipotezo zavrnili in nismo dokazali, da je poznavanje terminologije in namena vitkega proizvajanja na nizki ravni, da so se v povprečju anketirani najbolj strinjali s trditvijo, da vedo, kaj pomeni izraz vitko proizvajanje, in vedo, katera so njena orodja.

Slabše rezultate smo dobili pri trditvah, da o vitkem proizvajanju vedo toliko, da lahko svoje znanje delijo naprej, in da so dovolj izobraženi. Glede na te odgovore ter odgovore na deseto vprašanje, kjer je veliko anketiranih odgovorilo, da glede vpeljave $5 \mathrm{P}$ v podjetje predlagajo več usposabljanj na to temo, predlagamo, da $\mathrm{v}$ podjetju pripravijo načrt, kako usposobiti posamezne skupine zaposlenih. Tudi potrjena hipoteza H2 potrjuje zapisano, kjer nas je 
zanimalo, ali je poznavanje namena in terminologije vitkega proizvajanja boljše z večjim številom ur usposabljanja.

Hipotezo H3 smo glede na rezultat zavrnili in nismo mogli potrditi , da je poznavanje namena in terminologije vitkega proizvajanja boljše $\mathrm{z}$ višjo formalno izobrazbo.

Glede na rezultate analize v povprečju največ anketiranih pozna izraze kanban, 5 S, JIT in TPM, slabše poznajo izraze One Piece Flow, PDCA, SMED in Poka-Yoke, zelo slabo pa poznajo izraze Heijunka, Jidoka, Value Stream Mapping in Kaizen. V povprečju anketirani največ uporabljajo orodja 5 S, TPM, kanban, SMED, najmanj pa Heijunka, Jidoka, Value Stream Mapping in One Piece Flow. Menijo, da je najbolj učinkovito orodje za doseganje vitkega proizvajanja kanban, SMED, 5 S, TPM IN PDCA, JIT. Najmanj se jim zdi učinkovito Heijunka, Jidoka, Value Stream Mapping ter One Piece Flow. Iz rezultatov lahko razberemo, da anketirani bolj uporabljajo tista orodja, ki jih tudi bolj poznajo. Iz tega sklepamo, da bi pogosteje uporabljali tudi ostala orodja, če bi jih bolj spoznali. Orodja, ki jih uporabljajo, se jim zdijo tudi najbolj učinkovita, torej vidijo povezavo in smisel v tem, kar uporabljajo.

Tudi Hines in drugi (2012, str. 17) trdijo, da je angažiranost zaposlenih za uvajanje načel vitkosti ključna. Od nje sta odvisna njihovo vedenje in končni uspeh. Mnogo korakov vodi do angažiranosti, toda uspešna strategija, uskladitev in voditeljstvo so dober začetek. Vloga vodje je, da navdihuje z besedami, dejanji in ukrepi. Vsakomur v organizaciji naj bi zato omogočili, da sodeluje v strateškem procesu, in vse spodbujali, da se vključijo v izvedbo dejanskih sprememb ter okrepijo odpravljanje vzrokov namesto posledic in zmanjšajo obseg dela, ki ne ustvarja vrednosti.

\section{Zaključek}

Namen raziskave je bil predstaviti teoretična izhodišča $s$ področja vitkega proizvajanja $s$ poudarkom na usposabljanju zaposlenih ter ugotoviti stopnjo usposobljenosti o vitkem proizvajanju ter podati predloge za izboljšanje. Na vzorcu 342 zaposlenih v izbranem podjetju v organizacijski enoti proizvajanja, smo s pomočjo 1KA opravili anketiranje o poznavanju terminologije in namen vitkega proizvajanja. Vprašalnik je bil poslana na elektronske naslove vsem zaposlenim v proizvajanju. V povprečju največ anketiranih pozna izraze kanban, $5 \mathrm{~S}$, JIM in TPM. Anketirani so ocenili stopnjo vitkosti v podjetju in v veliki večini menijo, da je to nekje na srednji ravni, vendar bo na tem področju potrebnega še veliko dela. Tisti, ki so se usposabljanja udeležili, so se usposabljali v povprečju 14,8 ur.

$\mathrm{Na}$ podlagi pregleda strokovne literature, identificiranega raziskovalnega problema in zasnovanega vprašalnika smo preverjali tri hipoteze. Pri H1 nas je zanimalo, ali je poznavanje terminologije in namena vitkega proizvajanja na nizki ravni. Glede na povprečno vrednost smo hipotezo zavrnili in nismo uspeli dokazati, da je poznavanje terminologije in namena vitkega proizvajanja na nizki ravni. Zato sklepamo, da anketirani zaposleni poznajo terminologijo in namen vitkega proizvajanja. Pri H2 smo želeli ugotoviti ali se poznavanje namena in 
terminologije vitkega proizvajanja izboljšuje z večjim številom ur usposabljanja. Uporabili smo Pearsonov korelacijski koeficient in ugotovili, da gre za pozitivno povezanost spremenljivk. Hipotezo smo potrdili. Sledi ugotovitev, da več ur usposabljanja pomeni boljše poznavanje terminologije vitkega proizvajanja in namena vitkega podjetja. Pri H3 smo želeli raziskati, ali se poznavanje namena in terminologije vitkega proizvajanja izboljšuje z višjo formalno izobrazbo. Za analizo smo porabili ANOVO oz. analizo variance. Glede na rezultat nismo mogli potrditi, da je poznavanje namena in terminologije vitkega proizvajanja boljše $\mathrm{z}$ višjo formalno izobrazbo, zato smo hipotezo zavrnili.

Ugotovitve iz naše raziskave prinašajo tako teoretične kot praktične novosti ter nova znanja, ki predstavljajo pomemben prispevek k menedžerski znanosti in stroki s področja menedžmenta proizvajanja $\mathrm{z}$ osredotočenjem na usposabljanju za vitko proizvajanje $\mathrm{v}$ izbranem podjetju. Teoretični prispevek k menedžerski znanosti in stroki predstavljata celovita in sistematična analiza ter sinteza pojmov o vitkem proizvajanju. Na enem mestu smo zbrali ter opisali vsa bistvena načela in spoznanja o vitkosti, kot so npr. JIT, kanban, SMED, Jidoka, Heijunka, PDCA, TPM, 5 S - Five S, Kaizen, Poka-Yoke itd. Ugotovili smo, da so se raziskovalci doslej v svojih raziskavah ukvarjali predvsem z operativnim področjem v posameznem delovnem procesu in manj z izhodišči zanj. Ob pregledu dosedanjih raziskav nismo zasledili, da bi se kdo od slovenskih avtorjev ukvarjal s tematiko usposabljanja zaposlenih sodelavcev. V empiričnem delu raziskave smo prišli do novih znanj o stanju usposobljenosti za vitko proizvajanje, ki bodo imela teoretične in predvsem praktične koristi za izbrano organizacijo in širšo družbeno skupnost. Kot ključni prispevek k managerski znanosti in stroki iz empiričnega dela raziskave navedemo ugotovitev, da več ur usposabljanja o načelih vitkega proizvajanja pomeni boljše poznavanje terminologije vitkega proizvajanje in namena vitkega proizvajanja. Na podlagi predhodnih ugotovitev smo zasnovali predloge za izboljšanje stanja na področju usposobljenosti o vitkem proizvajanju v izbranem podjetju.

Po pregledu domače in tuje strokovne literature ter identificiranju raziskovalnega problema smo zaznali nekatere predpostavke in omejitve. Predpostavke: vitko proizvajanje je tematika, ki je v tuji strokovni literaturi s področja menedžmenta vredna pozornosti teoretikov, raziskovalcev in praktikov od 70-ih let preteklega stoletja dalje; do sedaj v RS še ni bilo opravljene nobene empirične raziskave o usposobljenosti zaposlenih o vitkem proizvajanju ter, da je vprašalnik najboljši pripomoček za pridobivanje podatkov o stopnji usposobljenosti zaposlenih o vitkem proizvajanju. Zaznali smo tudi omejitve, povezane $\mathrm{z}$ varovanjem podatkov podjetja in varovanjem osebnih podatkov zaposlenih; nismo proučevali vpliva usposobljenosti na dejavnike uspešnosti delovnih procesov, kot npr. na OEE; zadovoljstvo kupcev, kakovost izdelkov ipd.; raziskavo smo opravili v enem proizvodnem podjetju, zato izidov ne bo mogoče posploševati na druga podjetja in na druge dejavnosti.

Raziskave s področja usposobljenosti zaposlenih o vitkem proizvajanju v RS doslej še niso bile izvedene, zato naših rezultatov nismo mogli primerjati z nobeno podobno raziskavo. So pa pridobljeni rezultati iz naše raziskave lahko dobra podlaga za nadaljnje raziskovanje. Ker je 
bila raziskava izvedena samo $\mathrm{v}$ enem podjetju iz koncerna, se nadaljnje raziskovanje lahko izvede tako, da se anketiranje izvede tudi v drugih podjetjih in se jih lahko nato medsebojno tudi primerja. Nadalje bi bilo vsebinsko mogoče nadaljevati raziskovanje v smeri ugotavljanja vpliva usposobljenosti o vitkem proizvajanju na posamezne ali kompozitne kazalnike uspešnosti (poslovne, tehnološke ali celovite) organizacije. Prav tako bi bilo mogoče razširiti pregled doslej opravljenih raziskav v RS s tujimi raziskavami ter ugotoviti, ali je bila tematika usposabljanja o vitkem proizvajanju doslej proučevana tudi v širšem prostoru. Za pridobivanje podatkov o usposabljanju s področja vitkega proizvajanja bi bilo mogoče uporabiti tudi druge znanstvenoraziskovalne metode, kot npr. intervju, študijo primera ali uporabiti drug vprašalnik.

\section{ZAHVALA}

Prispevek je izdelan v sklopu projekta številka P5-0049, ki ga sofinancira Javna agencija za raziskovalno dejavnost Republike Slovenije iz državnega proračuna.

\section{Reference}

1. 1ka. (2017). Celovita podpora anketnemu procesu. Minimalno število klikov. Pridobljeno na https://www.1ka.si/.

2. Agencija Poti. (2013). Vitka proizvodnja-najbolj učinkoviti pristopi pri doseganju le-te. Pridobljeno na Http://www.agencija-poti.si/si/izobrazevanje/46986,149734/podrobno.html.

3. Črešnar, V. (2012). Kanban kot gradnik vitke proizvodnje (delo diplomskega seminarja). Maribor: Univerza v Mariboru, Ekonomsko-poslovna fakulteta.

4. Ferjančič, I. (2011). Uvajanje vitke proizvodnje v konkretnem podjetju s ciljem izboljšanja poslovanja (magistrsko delo). Ljubljana: Univerza v Ljubljani, Ekonomska fakulteta.

5. Gošnik, D. (2018). Model managementa temeljnih procesov in uspešnosti podjetja (doktorska disertacija). Koper: Univerza na Primorskem, Fakulteta za management.

6. Hines, P., Found, P., Griffiths, G. \& Harrison, R. (2012). Ohranjanje vitkosti: uspeti, ne le preživeti. Ljubljana: Slovenski institut za kakovost in meroslovje.

7. Kešetović, A. (2012). Filozofija vitke proizvodnje - koncept, ki prinaša poslovne uspehe. V Odzivi na gospodarsko krizo? Inovativnost, podjetništvo, trajnostni razvoj, 227-233. Koper: Univerza na Primorskem, Fakulteta za management.

8. Leskovšek, M. (2014). Vpliv vitkih principov proizvodnje/logistike na sistem planiranja v proizvodnih podjetjih (diplomsko delo univerzitetnega študijskega programa). Maribor: Univerza v Mariboru, Fakulteta za logistiko.

9. Liker, J. K. (2004). The Toyota way: 14 management principles from the world's greatest manufacturer. New York: McGraw-Hill.

10. Ljubič, T. (2000). Planiranje in vodenje proizvodnje. Kranj: Moderna organizacija.

11. Maurya, A. (2014). Delaj vitko. Ljubljana: Pasadena.

12. Molnar, S̆. (2009). Uvajanje vitke proizvodnje na področju trdnih farmacevtskih oblik (magistrsko delo). Ljubljana: Univerza v Ljubljani, Fakulteta za farmacijo.

13. Oražem, E. (2010). Prenova proizvodnje v izbranem podjetju (diplomsko delo). Nova Gorica: Univerza v Novi Gorici, Poslovno-tehniška fakulteta.

14. Page, J. (2004). Implementing lean manufacturing techniques: making your system lean and living with it. Cincinnati $(\mathrm{OH})$ : Hanser Gardner. 
15. Piškor, M. (2012). Uporaba orodij za doseganje vitke proizvodnje v podjetju Oprema - Uredaji d.d. (magistrsko delo). Maribor: Univerza v Mariboru, Fakulteta za strojništvo.

16. Pučko, D. (1993). Planiranje v podjetjih. Ljubljana: Univerza v Ljubljani, Ekonomska fakulteta.

17. Radoševič, A. (2008). Povečanje produktivnosti izdelave notranjih vrat $z$ vpeljavo vitkega proizvajanja (diplomska naloga). Koper: Univerza na Primorskem, Fakulteta za management Koper.

18. Sečki, M. (2011). Vitkost in njen vpliv na logistiko v proizvodnji (magistrsko delo). Maribor: Univerza v Mariboru, Fakulteta za logistiko.

19. Stewart, J. (2012). The Toyota kaizen continuum: a practical guide to implementing lean. Boca Raton: CRC Press.

20. Strašek, V. (2013). Vpliv uvajanja vitke proizvodnje na kakovost procesov v podjetju (magistrsko delo). Maribor: Univerza v Mariboru, Fakulteta za strojništvo in Ekonomsko-poslovna fakulteta.

21. Šverko, M. (2012). Uporaba načel vitke proizvodnje pri proizvodnji žarometov (magistrsko delo). Maribor: Univerza v Mariboru, Fakulteta za strojništvo.

22. Unterlechner, M., Meško Štok, Z. \& Markič, M. (2009). Inoviranje, kakovost in Lean Six Sigma v proizvodnem procesu. Koper: Univerza na Primorskem, Fakulteta za management.

23. Vergot, L. (2011). Aplikacija načel vitke proizvodnje pri izdelavi kompresorjev (diplomsko delo visokošolskega študija). Kranj: Univerza v Mariboru, Fakulteta za organizacijske vede Kranj.

24. Zelenika, R. (2000). Metodologija i tehnologija izrade znanstvenog i stručnog djela. Rijeka: Ekonomski fakultet.

25. Zigmund, M. (2009). Izboljšava upravljanja zalog po sistemu kanban v podjetju Roto Lož d.o.o. (diplomsko delo visokošolskega strokovnega študija). Kranj: Univerza v Mariboru, Fakulteta za organizacijske vede Kranj.

$$
* * *
$$

Sabina Zidar je magistrirala leta 2018 na Fakulteti za management Univerze na Primorskem s področja managementa logističnih storitev na temo vitke proizvodnje. $\mathrm{V}$ gospodarstvu je zaposlena dvanajsto leto, trenutno kot MRP planer.

Mirko Markič je doktoriral na Fakulteti za organizacijske vede Univerze v Mariboru s področja organizacijskih ved na temo inoviranja. Po dvanajstih letih delovanja v gospodarstvu se je zaposlil na Fakulteti za management Univerze na Primorskem. Je redni profesor za področje menedžmenta in znanstveni svetnik ter vodja ali član 15 raziskovalnih projektov in projektov z gospodarstvom. Njegova bibliografija obsega več kot 600 enot s področja upravnih in organizacijskih ved ter javnega zdravstva (varstvo pri delu).

\section{Abstract: \\ Introduction Lean Manufacturing Principles in the Chosen Company}

Research Question (RQ): What is the level of education/training about lean production?

Purpose: To conduct an empirical research based on the introduction of lean production, the level of knowledge and expertise in regards to the method and the general opinion about the introduction of lean production amongst the participants in the survey. 
Revija za univerzalno odličnost / Journal of Universal Excellence,

Marec / March 2020, leto / year 9, številka / number 1, str. / pp. 1-15.

Method: Based on a sample of 342 employees in chosen company we have conducted a quantitative research about the expertise and the introduction of the principals of lean production.

Results: The key conclusion from the empirical part of the research is that more hours of education/training means a better knowledge of both the terminology of lean production and the purpose of a lean company.

Organization: We have designed propositions for the improvement of the current level of expertise and the introduction of the principals of lean production.

Society: Findings from this research will have theoretical and practical implications for all who try to introduce the principals of lean production in the future.

Originality: Original research on employees' education/training in lean manufacturing in the Republic of Slovenia.

Limitations/Future Research: The survey was conducted in one manufacturing company, so the results will not be generalizable to other companies and other economic activity.

Keywords: lean production, management, production, training.

Copyright (c) Sabina ZIDAR \& Mirko MARKIČ

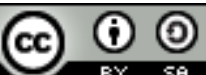

Creative Commons License

This work is licensed under a Creative Commons Attribution-ShareAlike 4.0 International License. 